\title{
Soil Contamination by Heavy Metals and Metalloids
}

\author{
Dionisios Gasparatos
}

Laboratory of Soil Science and Agricultural Chemistry, Agricultural University of Athens, 75 Iera Odos Street, 11855 Athens, Greece; gasparatos@aua.gr

Soils are central to life on Earth because they provide food, clean water, and air due to their filtering capacity; raw materials; habitats for living organisms; and climate resilience via carbon sequestration, therefore supporting a variety of ecosystem services [1]. Despite this, soil's life-sustaining functions have been underestimated until recently, and few people seem to be aware of them. It is now clear that soil plays an active role in maintaining life and that life is unable to exist without it. The insights about soils that have been gleaned over the last few decades have revealed that these complex systems are fragile, scarce, non-renewable, threatened resources as well as a crucial link between local and global environmental issues. Healthy soils are critical to achieving the Sustainable Development Goals (SDGs) outlined in the United Nations and the Europe Green Deal strategy [2]. In the Europe context, it is estimated that between 60 and $70 \%$ of EU soils are unhealthy due to erosion, contamination, compaction, carbon depletion, biodiversity loss, and sealing.

Soil contamination has been identified and as one of the main threats to soil, inducing the degradation of global soils and driving long-term losses of the ecosystem services that they provide. As a result of human activities, the amount of soil contamination caused by heavy metal(loid)s has severely increased over the last few decades and has become a worldwide environmental issue that has attracted considerable public attention [3,4]. Soil contamination changes biota composition and affects water, air, and food quality, degrading human health. Although many research efforts have highlighted how soil contamination is a global threat, providing an overview of the importance of healthy soil, there is still a great need for additional information from different regions around the world, and concrete strategies, which can be implemented to address the causes and impacts of this major threat, urgently need to be developed.

In this context, this Special Issue was launched with the scope of bringing together articles presenting the development of novel science-based methods and applications that enhance the remediation of contaminated soil by focusing on (1) the identification of the main sources of soil contamination caused by heavy metal(loid)s (HM)/potentially toxic elements (PTEs) in different soil types, (2) the chemistry, speciation, potential mobility, and bioavailability of the contaminants that are commonly found in contaminated soils, (3) the assessment of the negative impacts and risks associated with HM/PTE-induced soil contamination on crop yields, soil biota, food security, and human health, (4) the available methods and strategies for monitoring, assessing, and remediating soils that have been contaminated by HM/PTEs, and (5) guidelines that include threshold values for HM/PTE levels in soils at national and regional levels.

$\mathrm{HM} / \mathrm{PTE}$ contamination in anthropogenic urban soils constitute a major environmental problem, and therefore, urban soils are often subject to detailed risk-assessment and management studies $[5,6]$. Contamination is often assessed in terms of total concentrations, revealing possible soil enrichment due to heavy metals, and is used to establish regulatory guidelines for policy decisions. However, various authors have recognized that it is the bioavailability of metals that determines their fate and behavior in the environment $[7,8]$. In this respect, the article of Moreno-Alvarez et al. [9] focuses on the pseudo-total, -available,

and -acid-oxalate concentrations that are extractable from urban soils of Havana, Cuba.

Copyright: (c) 2022 by the author Licensee MDPI, Basel, Switzerland. This article is an open access article distributed under the terms and conditions of the Creative Commons Attribution (CC BY) license (https:// creativecommons.org/licenses/by/ $4.0 /)$. 
They observe that the pseudo-total concentrations were generally higher than the average values for the world's soils that they were similar to those published for urban soils. Moreover, the study shows that Fe, Ti, V, Ni, Cr, and Co were mainly of lithological origin, whereas the contribution of anthropogenic sources related to industrial activities, fuel combustion, and the application of organic amendments to soil were connected to $\mathrm{Cr}$, As, $\mathrm{Hg}, \mathrm{Pb}, \mathrm{Zn}, \mathrm{Cd}$, and $\mathrm{Cu}$ levels. The toxicity limits for the bioavailability of $\mathrm{Cd}, \mathrm{Ni}, \mathrm{Mn}$, and $\mathrm{Pb}$ were exceeded by $14 \%, 10 \%, 39 \%$, and $56 \%$ of samples, respectively; therefore, the authors argue that guidelines underlining the safety limits for the better management of the urban agriculture activities should be introduced.

As they comprise a significant part of urban ecosystems, roadside soils have attracted the interest of researchers for at least four decades [10]. Roadside soils are greatly affected by man-made changes that affect their physicochemical and biological properties, and many studies have pointed out that the metal concentrations in these soils depend on traffic intensity. In that context, De Silva et al. [11] deal with the bioavailability of metals aged in roadside soils in situ. Using soil samples collected from sites representing three road of different ages (new, medium, and old roads) and different techniques (diffusive gradients in thin films technique, soil water extraction, $\mathrm{CaCl}_{2}$ extraction, total metal concentrations, and optimized linear models), the study provides insights into the kinetics of the long-term metal aging that causes metal bioavailability to decrease over time.

Although some PTEs such as Selenium (Se) are considered essential micronutrients at low concentrations, they can be hazardous to human health at concentrations exceeding tolerable doses [12]. Given this constrain, Zafeiriou et al. [13] examined the adsorption and desorption processes of Se(IV) that had been freshly added to acid and alkaline soils, aiming to describe the Se's geochemistry in terms of its bioavailability and contamination risk via leaching. The acidic soils adsorbed significantly higher amounts of the added Se(IV) than the alkaline soils did, and the alkaline soils desorbed more Se. Taking into consideration that biofortification through plant uptake is also crop/plant-dependent, the application of Se(IV) to agricultural soils should be site-specific, as Se poses a high leaching hazard risk in alkaline soils with low concentrations of metal oxides, while low Se availability may result in acidic soils with a high metal oxide content.

Several soil remediation strategies have been used among the scientific community in the last twenty years [14]. The application of low-cost and eco-friendly materials as immobilizing agents in HM/PTEs-contaminated soils has gained significant interest, and there is now an urgent need to understand their functionality in contaminated soils [15]. The extensive application of biochar, which acts as a contaminant scavenger, has received significant consideration for HM/PTE-contaminated soil remediation [16,17].

In this respect, the article by Cui et al. [18] focuses on the effect of wheat straw biochar on soil $\mathrm{Cd}$ and $\mathrm{Pb}$ bioavailability, uptake, and translocation by rice in a contaminated paddy soil. They observed that biochar application reduced $\mathrm{Cd}(16.1-84.1 \%)$ and $\mathrm{Pb}(4.1-40.0 \%)$ transfer from root to rice grain, simultaneously improving physicochemical (moisture content, $\mathrm{pH}$, organic matter) and biological (enzymatic activity and microbial community structure) properties of the soil. According to the authors, understanding the role of biochar at the atomic level is critical to unraveling the mechanisms by which biochar stabilizes in situ heavy metals over longer time periods and in different soil types.

Phytoextraction, a strategy that uses plants to accumulate HM/PTEs in the biomass, is an alternative approach to restore contaminated soils and that has several limitations impeding its use in commercial applications $[19,20]$. As a practical example of this phytoremediation approach, Antonangelo and Zhang [21] dealt with the influence of nitrogen $(\mathrm{N})$ added via biochars from different feedstocks on the cadmium $(\mathrm{Cd})$ removal ability by ryegrass. Interestingly the authors applied different biochar doses to shows how $\mathrm{N}$ accumulation increases as a function of the biochar application rate, and this increase contributed to higher ryegrass yield and $\mathrm{Cd}$ accumulation.

Microbially-assisted phytoremediation is an innovative strategy that is based on the use of plant growth-promoting rhizobacteria (PGPRs) to enhance the phytoremediation 
efficiency [22]. In this respect, the article by Zafar-ul-Hye [23] focuses on the effect of Stenotrophomonas maltophilia and Agrobacterium fabrum to improve nutrient uptake and to alleviate the adverse effects of $\mathrm{Cd}$ in bitter gourd. The results showed that the treatment of A. fabrum combined with NPK fertilizers showed an increase in the number of bitter gourds per plant (34\% and $68 \%)$; fruit length $(19 \%$ and $29 \%)$; bitter gourd yield $(26.5 \%$ and $21.1 \%)$; and $\mathrm{N}(48 \%$ and $56 \%)$ and $\mathrm{K}(72 \%$ and $55 \%)$ concentrations of the control grown under different soil cadmium concentration ( 2 and $5 \mathrm{mg} \mathrm{kg}^{-1}$ soil). The study concluded that A. fabrum is more effective that S. maltophilia in alleviating Cd-induced stress in bitter gourd.

Despite the increasing awareness of soil degradation due to contamination, as pointed out in this Special Issue, much more research is needed to better understand the behavior of HM/PTEs in soils with different pedoclimatic conditions, their interactions with soil components, and the development innovative and efficient remediation procedures for the recovery of contaminated soils.

Acknowledgments: I would like to express my sincere gratitude to the authors who contributed to this Special Issue, to the reviewers for their valuable assistance as well as to the staff of MDPI for their efforts to complete and publish this issue.

Conflicts of Interest: The author declares no conflict of interest.

\section{References}

1. Baveye, P.C.; Baveye, J.; Gowdy, J. Soil "ecosystem" services and natural capital: Critical appraisal of research on uncertain ground. Front. Environ. Sci. 2016, 4, 41. [CrossRef]

2. Lal, R.; Bouma, J.; Brevik, E.; Dawson, L.; Field, D.J.; Glaser, B.; Hatano, R.; Hartemink, A.E.; Kosaki, T.; Lascelles, B.; et al. Soils and sustainable development goals of the United Nations: An International Union of Soil Sciences perspective. Geoderma Reg. 2021, 25, e00398. [CrossRef]

3. Tóth, G.; Hermann, T.; Da Silva, M.R.; Montanarella, L. Heavy metals in agricultural soils of the European Union with implications for food safety. Environ. Int. 2016, 88, 299-309. [CrossRef] [PubMed]

4. Alengebawy, A.; Abdelkhalek, S.T.; Qureshi, S.R.; Wang, M.Q. Heavy metals and pesticides toxicity in agricultural soil and plants: Ecological risks and human health implications. Toxics 2021, 9, 42. [CrossRef]

5. Massas, I.; Gasparatos, D.; Ioannou, D.; Kalivas, D. Signs for secondary build up of heavy metals in soils at the periphery of Athens International Airport, Greece. Environ. Sci. Poll. Res. 2018, 25, 658-671. [CrossRef]

6. Herbón, C.; Barral, M.T.; Paradelo, R. Potentially toxic trace elements in the urban soils of Santiago de Compostela (Northwestern Spain). Appl. Sci. 2021, 11, 4211. [CrossRef]

7. Zafeiriou, I.; Gasparatos, D.; Kalyvas, G.; Ioannou, D.; Massas, I. Desorption of arsenic from calcareous mine affected soils by phosphate fertilizers application in relation to soil properties and As partitioning. Soil Syst. 2019, 3, 54. [CrossRef]

8. Antoniadis, V.; Shaheen, S.M.; Boersch, J.; Frohne, T.; Laing, G.D.; Rinklebe, J. Bioavailability and risk assessment of potentially toxic elements in garden edible vegetables and soils around a highly contaminated former mining area in Germany. J. Environ. Manag. 2017, 186, 192-200. [CrossRef]

9. Moreno-Alvarez, J.M.; Orellana-Gallego, R.; Fernandez-Marcos, M.L. Potentially Toxic Elements in Urban Soils of Havana, Cuba. Environments 2020, 7, 43. [CrossRef]

10. Werkenthin, M.; Kuge, B.; Wessolek, G. Metals in European roadside soil and soil solution-A review. Environ. Pollut. 2014, 189, 98-110. [CrossRef]

11. De Silva, S.; Huynh, T.; Ball, A.S.; Indrapala, D.V.; Reichman, S.M. Measuring Soil Metal Bioavailability in Roadside Soils of Different Ages. Environments 2020, 7, 91. [CrossRef]

12. Zafeiriou, I.; Gasparatos, D.; Ioannou, D.; Kalderis, D.; Massas, I. Selenium Biofortification of Lettuce Plants (Lactuca sativa L.) as Affected by Se Species, Se Rate, and a Biochar Co-Application in a Calcareous Soil. Agronomy 2022, 12, 131. [CrossRef]

13. Zafeiriou, I.; Gasparatos, D.; Massas, I. Adsorption/Desorption Patterns of Selenium for Acid and Alkaline Soils of Xerothermic Environments. Environments 2020, 7, 72. [CrossRef]

14. Kalyvas, G.; Gasparatos, D.; Liza, C.A.; Massas, I. Single and combined effect of chelating, reductive agents, and agroindustrial by-product treatments on $\mathrm{As}, \mathrm{Pb}$, and $\mathrm{Zn}$ mobility in a mine-affected soil over time. Environ. Sci. Pollut. Res. 2020, 27, 5536-5546. [CrossRef]

15. Palansooriya, K.N.; Shaheen, S.M.; Chen, S.S.; Tsang, D.C.W.; Hashimoto, Y.; Hou, D.; Bolan, N.S.; Rinklebe, J.; Ok, Y.S. Soil amendments for immobilization of potentially toxic elements in contaminated soils: A critical review. Environ. Int. 2020, 134, 105046. [CrossRef]

16. He, L.; Zhong, H.; Liu, G.; Dai, Z.; Brookes, P.C.; Xu, J. Remediation of heavy metal contaminated soils by biochar: Mechanisms, potential risks and applications in China. Environ. Pollut. 2019, 252, 846-855. [CrossRef] 
17. Bilias, F.; Nikoli, T.; Kalderis, D.; Gasparatos, D. Towards a Soil Remediation Strategy Using Biochar: Effects on Soil Chemical Properties and Bioavailability of Potentially Toxic Elements. Toxics 2021, 9, 184. [CrossRef]

18. Cui, L.; Li, L.; Bian, R.; Yan, J.; Quan, G.; Liu, Y.; Ippolito, J.A.; Wang, H. Short- and Long-Term Biochar Cadmium and Lead Immobilization Mechanisms. Environments 2020, 7, 53. [CrossRef]

19. Kalyvas, G.; Tsitselis, G.; Gasparatos, D.; Massas, I. Efficacy of EDTA and Olive Mill Wastewater to Enhance As, Pb, and Zn Phytoextraction by Pteris vittata L. from a Soil Heavily Polluted by Mining Activities. Sustainability 2018, 10, 1962. [CrossRef]

20. Ashraf, S.; Ali, Q.; Zahir, Z.A.; Ashraf, S.; Asghar, H.N. Phytoremediation: Environmentally sustainable way for reclamation of heavy metal polluted soils. Ecotoxicol. Environ. Saf. 2019, 174, 714-727. [CrossRef]

21. Antonangelo, J.; Zhang, H. Influence of Biochar Derived Nitrogen on Cadmium Removal by Ryegrass in a Contaminated Soil. Environments 2021, 8, 11. [CrossRef]

22. Gul, I.; Manzoor, M.; Hashim, N.; Shah, G.M.; Waani, S.P.T.; Shahid, M.; Antoniadis, V.; Rinklebe, J.; Arshad, M. Challenges in Microbially and Chelate-Assisted Phytoextraction of Cadmium and Lead-A Review. Environ. Pollut. 2021, 287, 117667. [CrossRef] [PubMed]

23. Zafar-ul-Hye, M.; Naeem, M.; Danish, S.; Fahad, S.; Datta, R.; Abbas, M.; Rahi, A.A.; Brtnicky, M.; Holátko, J.; Tarar, Z.H.; et al. Alleviation of Cadmium Adverse Effects by Improving Nutrients Uptake in Bitter Gourd through Cadmium Tolerant Rhizobacteria. Environments 2020, 7, 54. [CrossRef] 